\title{
Effects of fixation and processing on immunohistochemical demonstration of immunoglobulin in paraffin sections of tonsil and bone marrow
}

\author{
RC CURRAN AND J GREGORY
}

From the Department of Pathology, Medical School, University of Birmingham B15 2TJ, UK

SUMMARY A number of fixatives were tested to determine their suitability for use with the unlabelled antibody peroxidase-antiperoxidase (PAP) method for demonstrating immunoglobulin in paraffin sections of tonsil and trephine samples of bone marrow. It was found that tonsil fixed in 'isotonic' solutions of formaldehyde reacted with the PAP method only after the sections had been trypsinised. Several other fixatives, including Bouin's fluid, Carnoy's fluid, and solutions containing mercuric chloride, gave tissues which reacted without trypsinisation of sections, and particularly good results were obtained with formol saline to which acetic acid (2-10\%) had been added. A combination of acetic acid (10\%)-formol saline and formol sublimate also gave excellent results with bone marrow. The influence on the PAP method of a number of steps in the processing of tissues and sections was also examined.

Following the demonstration of immunoglobulin (Ig) in paraffin sections of formalin-fixed tissues by a peroxidase-based immunohistochemical technique, ${ }^{1}$ many pathologists have used the method but with varying degrees of success. Most used formaldehyde as the fixative, and the role of fixation as a cause of failure became obvious when it was found that tissues fixed in an unbuffered (aqueous) solution of formaldehyde gave better results than those fixed in 'isotonic' solutions of the same fixative $;^{2}$ and when sections of unreactive tissues were trypsinised, Ig-containing cells could be readily demonstrated in them, confirmation that fixation had merely masked the antigen (Ig) and not destroyed it. ${ }^{34}$ To clarify further the influence of fixation and to try to eliminate the need for trypsinisation, a series of fixative solutions has been tested. At the same time, the effect of the other steps in the processing of the tissues and of sections was investigated. Two tissues were studied: human tonsil which, apart from the crypt epithelium, consists largely of hyperplastic lymphoid tissue and contains a large population of Ig-containing cells; ${ }^{2}$ and a series of trephine specimens of human bone marrow.

Received for publication 25 March 1980

\section{Material and methods}

FIXATIVES

The following solutions were used (Table 1):

Solution 1 Buffered formaldehyde $4 \%$ formaldehyde (prepared from paraformaldehyde or from $40 \%$ formalin BP) in $0.135 \mathrm{M}$ phosphate buffer to which $2 \%$ sucrose was sometimes added. Carson's modification of Millonig's fixative ${ }^{5}$ was also used occasionally.

Solution 2 Formol saline $4 \%$ formaldehyde (prepared from paraformaldehyde or from $40 \%$ formalin BP) in $0.85 \%$ sodium chloride $(\mathrm{NaCl})$ solution, with or without $2 \%$ sucrose. The following concentrations of formaldehyde (in $0.85 \% \mathrm{NaCl}$ ) were also used: $0.1 \%, 0.5 \%, 1 \%$, and $2 \%$. Various concentrations of $\mathrm{NaCl}$ were also tested (with $4 \%$ formaldehyde but no sucrose): $0.2 \%, 0.4 \%, 0.6 \%, 0.8 \%$, and $2 \%$.

Solution 3 Aqueous formaldehyde $4 \%$ formaldehyde in water.

Solution 4 Acetic acid-formol saline The following concentrations of acetic acid were added to formol 
Table 1 Fixative solutions

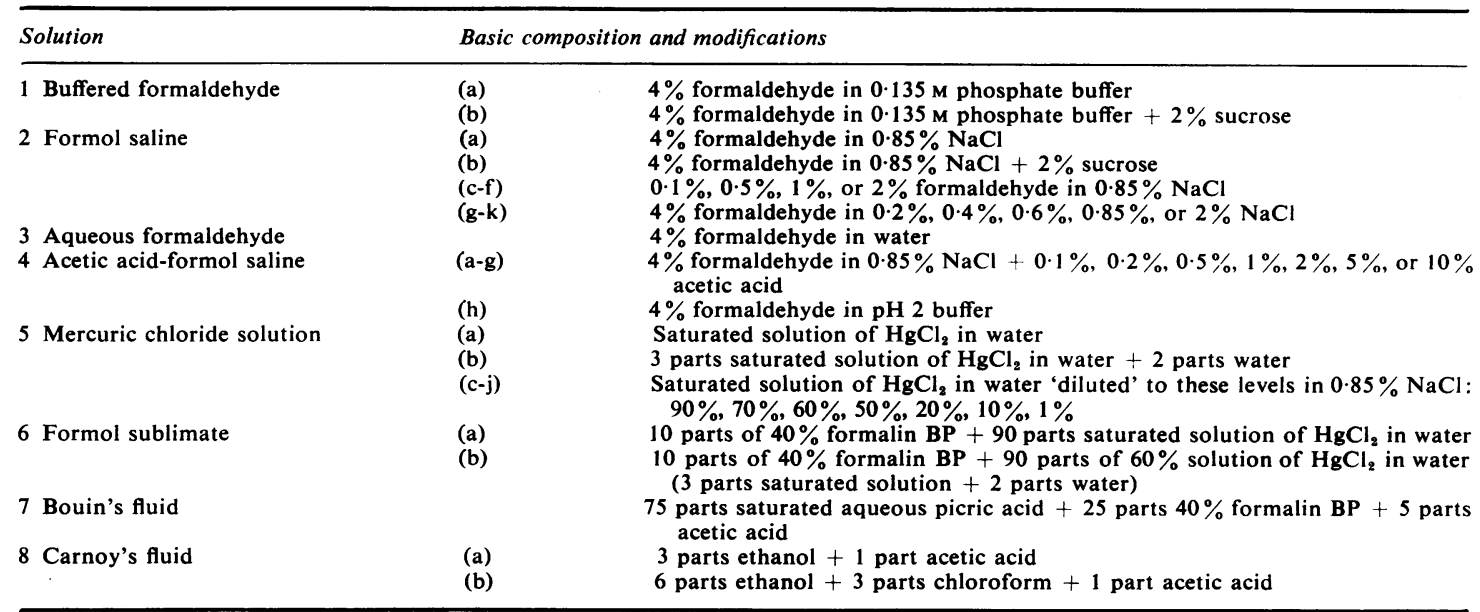

saline (without added sucrose): $0.1 \%, 0.2 \%, 0.5 \%$, $1 \%, 2 \%, 5 \%$, and $10 \%$. The pH of the solutions with the higher concentrations of acetic acid is approximately 2 , and for comparison $4 \%$ formaldehyde in buffer pH 2 (Walpole) was tested.

Solution 5 Mercuric chloride $\left(\mathrm{HgCl}_{2}\right)$ solution Saturated $(7 \%)$ solution of $\mathrm{HgCl}_{2}$ in water and a more dilute solution of $\mathrm{HgCl}_{2}$ ( 2 parts of water +3 parts of the saturated solution) were used, as were solutions prepared from saturated $\mathrm{HgCl}_{2}$ solution by 'diluting' it to the following levels by the addition of $0.85 \% \mathrm{NaCl}$ solution: $90 \%, 70 \%, 60 \%, 50 \%, 20 \%$, $10 \%$, and $1 \%$.

Solution 6 Formol sublimate 10 parts of $40 \%$ formalin $\mathrm{BP}+90$ parts saturated aqueous $\mathrm{HgCl}_{2}$. Sometimes $60 \%$ aqueous $\mathrm{HgCl}_{2}$ solution was substituted for the saturated $\mathrm{HgCl}_{2}$ solution.

Solution 7 Bouin's fluid 75 parts saturated aqueous picric acid +25 parts $40 \%$ formalin BP +5 parts acetic acid.

\section{Solution 8 Carnoy's fluid:}

Fluid 13 parts ethanol +1 part acetic acid; and

Fluid 26 parts ethanol +3 parts chloroform + 1 part acetic acid.

\section{FIXATION PROCEDURES}

Fixation was carried out at $20^{\circ} \mathrm{C}$ unless otherwise stated.

HUMAN TONSIL

Slices (approx. $2 \mathrm{~mm}$ thick) of 26 fresh human tonsils were fixed in each of the above solutions. The period of fixation was 24-48 hours in solutions 1 to 7 and 3 hours in solution 8 . A portion of every specimen was fixed in buffered formaldehyde (solution 1) or formol saline (solution 2$)(2 \%$ sucrose was often added to these solutions). Some tissues fixed in them were also postfixed for $\mathbf{2 4}$ hours in formol sublimate (solution 6) or in acetic acid (2\%)-formol saline (solution 4). Other tissues were fixed for 1, 2, 6, 48, 72 , or 96 hours in acetic acid (5\%)-formol saline (solution 4 ) or for 15 minutes to 4 hours in formol sublimate (solution 6) before fixation for 24-48 hours in acetic acid (5\%)-formol saline.

To test whether 'controlled autolysis' would improve the immunohistochemical response of tissues, slices of fresh tonsil were left in $0.135 \mathrm{M}$ phosphate buffer or buffer $+2 \%$ sucrose for 24 hours at $4{ }^{\circ} \mathrm{C}$ before fixation in buffered formaldehyde $(4 \%)$ or in formol saline. For the same reason other slices were lightly fixed in formol saline ( 24 hours at $4^{\circ} \mathrm{C}$ ) before soaking for 1-18 hours in $0.25 \%$ saline.

\section{Bone marrow}

Forty-two trephine samples of bone marrow, obtained from the posterior iliac crest, were fixed in acetic acid $(10 \%)$-formol saline for 48 hours. The fixative was changed four times and constantly agitated. Before being subjected to this procedure, 10 of the specimens were fixed for 24 hours in acetic acid (2\%)-formol saline and 25 were fixed for 4 hours in formol sublimate.

\section{PROCESSING OF TISSUES}

The tissues were dehydrated in ethanol (for approx. 24 hours), cleared in chloroform (6-9 hours), and impregnated (12-24 hours) in paraffin wax or 
Paraplast (paraffin wax + plastic polymers). Several changes of each reagent were used. In addition, some slices of tissue fixed in solution 1 or solution 2 were left for three days in either alcohol, xylol, chloroform, or molten $\left(56^{\circ} \mathrm{C}\right)$ paraffin wax before embedding, to determine the effect on the immunohistochemical response of the tissues.

\section{IMMUNOHISTOCHEMISTRY}

Immunoglobulin $(\gamma, \alpha$ and $\mu$ heavy chains; $\kappa$ and $\lambda$ light chains) was demonstrated by the unlabelled antibody peroxidase-antiperoxidase (PAP) procedure. ${ }^{6}$ Sections 3-4 $\mu \mathrm{m}$ thick were normally used but sections ranging in thickness from 2 to $18 \mu \mathrm{m}$ were also tested to determine the optimum thickness. The sections were dewaxed in xylol and brought to phosphate $(0.135 \mathrm{M})$ buffer through ethanol; and if the fixative had contained mercury, they were also treated with alcohol-iodine or Lugol's solution to remove the mercury. Trypsinised sections (5-30 minutes at $37^{\circ} \mathrm{C}$ with $0.1 \%$ trypsin in Tris-saline buffer, pH 7.8) and untrypsinised sections of all specimens were routinely used. Untrypsinised sections of tissues fixed in solutions 1 and 2 , which had been left for up to seven days in either xylol, chloroform, or water in an attempt to improve their response to the
PAP method, were also used.

The sections were subjected to the following steps:

(a) $0 \cdot 2 \%$ hydrochloric acid $(\mathrm{HCl})$ in methanol for 30 minutes at $20^{\circ} \mathrm{C}$ (to block endogenous peroxidase);

(b) several changes of Tris-saline-sucrose buffer (pH 7.6) $(15$ vol $0 \cdot 1 \mathrm{~N} \mathrm{HCl}, 10$ vol $0 \cdot 2 \mathrm{M}$ Tris, 15 vol normal saline $+2.5 \%$ sucrose);

(c) normal (non-immune, non-conjugated) swine serum 1 in 3 in Tris-saline buffer for 10 minutes (it was then tipped off);

(d) rabbit anti-human Ig antiserum* diluted in Tris-saline buffer (for titres, see Table 2 ) for $45 \mathrm{~min}$ utes (occasionally increased to 20 hours);

(e) Tris-saline-sucrose buffer (stirred) for 20 minutes;

$(f)$ swine anti-rabbit $\mathrm{Ig}$ antiserum (1 in 100 in Tris-saline buffer) for 45 minutes;

$(g)$ Tris-saline-sucrose buffer for 20 minutes;

(h) PAP complex (diluted 1 in 50 in Tris-saline buffer) for 45 minutes;

(i) Tris-saline-sucrose buffer for 20 minutes;

$(j)$ freshly made $0.05 \% 3,3^{\prime}$-diaminobenzidine

*The reagents (to detect $\gamma, a$ and $\mu$ heavy chains and $\kappa$ and $\lambda$ light chains) were: Dakopatts 10-090, 10-MAT, 10-091, 10-9K2, 10-9L2, 21-090, Z113 (obtained from Mercia Brocades Ltd., Watford).

Table 2 Influence of fixation on PAP method and histological structure

\begin{tabular}{|c|c|c|c|c|c|c|c|}
\hline \multirow{2}{*}{\multicolumn{2}{|c|}{ Fixative solution }} & \multicolumn{5}{|l|}{ PAP method } & \multirow{2}{*}{$\begin{array}{l}\text { Preservation } \\
\text { histological } \\
\text { structure }\end{array}$} \\
\hline & & $\begin{array}{l}\text { Stage }(d) \text { (specific antibo } \\
\text { and } \lambda \text { light chains) }\end{array}$ & dy against $\kappa$ & (Stage $(f)$ & $\begin{array}{l}\text { Stage }(h) \\
(P A P \text { complex })\end{array}$ & $\begin{array}{l}\text { Number of } \\
\text { Ig-containing } \\
\text { cells }\end{array}$ & \\
\hline 1 & $\begin{array}{l}\text { Buffered formalde- } \\
\text { hyde (with or } \\
\text { without } 2 \% \text { sucrose) }\end{array}$ & $\frac{1}{250}-\frac{1}{500}($ trypsinised $s$ & sections) & $\frac{1}{100}$ & $\frac{1}{50}$ & $++\underset{\text { sections }-)}{\text { (untrypsinised }}$ & +++ \\
\hline 2 & $\begin{array}{l}\text { Formol saline (with } \\
\text { or without } 2 \% \\
\text { sucrose) }\end{array}$ & $\frac{1}{250}-\frac{1}{500}$ (trypsinised se & sections) & $\frac{1}{100}$ & $\frac{1}{50}$ & $++\underset{\text { sections }- \text { ) }}{\text { (untrypsinised }}$ & +++ \\
\hline 3 & $\begin{array}{l}\text { Aqueous formal- } \\
\text { dehyde }\end{array}$ & $\frac{1}{250}-\frac{1}{500}$ & & $\frac{1}{100}$ & $\frac{1}{50}$ & 土 or - & ++ \\
\hline \multirow[t]{2}{*}{4} & $\begin{array}{l}\text { Acetic acid-formol } \\
\text { saline }\end{array}$ & (a) 5 or $10 \%$ acetic acid & $d: \frac{1}{200}-\frac{1}{1,000}$ & $\frac{1}{100}$ & $\frac{1}{50}$ & ++ & ++ \\
\hline & & (b) $2 \%$ acetic acid: & $\frac{1}{2,000}-\frac{1}{10,000}$ & $\frac{1}{100}$ & $\frac{1}{50}$ & $++t$ & +++ \\
\hline 5 & Mercuric chloride & $\frac{1}{250}-\frac{1}{500}$ & & $\frac{1}{100}$ & $\frac{1}{50}$ & ++ & ++ \\
\hline 6 & Formol sublimate & $\frac{1}{250}-\frac{1}{500}$ & & $\frac{1}{100}$ & $\frac{1}{50}$ & ++ & +++ \\
\hline 7 & Bouin's fluid & $\frac{1}{250}-\frac{1}{500}$ & & $\frac{1}{100}$ & $\frac{1}{50}$ & $+t$ & ++ \\
\hline 8 & Carnoy's fluid & $\frac{1}{10,000}-\frac{1}{30,000}$ & & $\frac{1}{100}$ & $\frac{1}{50}$ & ++ & + \\
\hline
\end{tabular}

Note: For $\gamma$ and $a$ heavy chains, the titre for stage (d) was usually about $\frac{1}{2}$ of those shown above, ie, $\frac{1}{125}-\frac{1}{250}$, and for $\mu$ heavy chains it was about $\frac{1}{4}$. 
tetrahydrochloride (DAB)-peroxide solution $(5 \mathrm{mg}$ DAB in $10 \mathrm{ml}$ Tris-saline buffer plus 1 drop $(0.025 \mathrm{ml})$ of $30 \%(100 \mathrm{vol})$ hydrogen peroxide $\left(\mathrm{H}_{2} \mathrm{O}_{2}\right)$ ) for 5 minutes;

$(k)$ water, then Mayer's haemalum for 20 seconds, followed by blueing, dehydration, clearing, and mounting in Canada balsam.

All steps were carried out at room temperature $\left(20^{\circ} \mathrm{C}\right)$, and in steps (c), (d), (f), and (h) the sections were placed on a rocker tray (Denley Instruments).

\section{Controls}

Sections were treated with DAB-peroxide solution alone; normal (non-immune) rabbit serum was used in place of the specific antiserum in stage (d); and in stage $(f)$ or (h) buffer was substituted for the antiserum. The addition of an equal volume of a range of dilutions ( 1 in 40 to 1 in 2560 ) of $\mathrm{IgG}$ $(10.5 \mathrm{mg} / \mathrm{ml})$ or $\operatorname{IgA}$ or $\operatorname{IgM}(1.5 \mathrm{mg} / \mathrm{ml})$ to the specific antiserum blocked the reaction for the appropriate heavy chain. The use of five different antisera in stage (d) also provided a form of control, since each identified a different population of cells. Counts of the number of Ig-containing cells in a series of bone marrows showed that the ratio of cells containing $\kappa$ chains to those containing $\lambda$ chains was 1.6:1 and that the total number of cells containing $\gamma, \alpha$, or $\mu$ heavy chains was invariably within a few per cent of the number containing $\kappa$ or $\lambda$ chains. The $\kappa$ and $\lambda$ antisera were also tested against sections of known monoclonal myelomatous deposits in marrow.

With every specimen a range of titres was used for stage (d) of the PAP sequence, to determine the optimum titre (Table 2). The optimum titre method is influenced not only by fixation and processing but also by the particular antibody used (and even with the particular batch). With antisera against $\kappa$ and $\lambda$ chains, it is generally between 1 in 250 and 1 in 500 with the control sections of tissues (fixed in solutions 1 or 2$)$, but with tissues fixed in acetic acid ( $2 \%)$ formol saline (solution 4) it is sometimes 1 in 10000 and with Carnoy's fluid (solution 8 ) it may be 1 in 20000 or more (Table 2). The titre for the antisera against $\gamma$ and $\alpha$ heavy chains is usually about half that for $\kappa$ and $\lambda$ chains, and for $\mu$ chains it is about a quarter (1 in 50 or 1 in 100).

Determining the optimum titre reduced or abolished non-specific reactions and avoided the prozone phenomenon which readily produces a false-negative result with a too-low titre. It also allowed valid comparisons to be made between the various fixation/processing sequences. To determine it, the following criteria were used: the intensity of the reaction (ideally a deep brown-black colour) in the cytoplasm of mature plasma cells; the number of Ig-containing cells (and, particularly, of those with low concentrations of cytoplasmic Ig); the intensity of reaction given by the serum in veins; and the level of background staining.

The influence of a fixative or variation in processing procedure on the response of a tissue to the PAP method was assessed by comparing the response of an untrypsinised section at optimum titre with that of an optimally trypsinised section of control tissue (fixed in solutions 1 or 2). The main criteria in deciding which of the two preparations was the better were the number of cells containing Ig (and particularly those containing small amounts of cytoplasmic Ig) and the precision of location of the Ig within the cells (Table 2). Each of the many fixation-processing sequences tested had its own set of blocks from which similar blocks of tissue, each containing a length of crypt epithelium and a lymphoid follicle with a well-developed germinal centre, were chosen. Subjective estimates were made of the numbers of Ig-containing cells in these (Table 2). When the differences between two preparations were slight, a comparison microscope was used.

\section{HISTOLOGY}

Sections of all specimens were stained with Harris's haematoxylin and eosin.

\section{Results}

TONSIL

Solutions 1 and 2-Buffered formaldehyde and formol saline

The histological structure of the tonsil is well preserved, cell boundaries being intact and welldefined, particularly when the fixative contained $2 \%$ sucrose. The lymphoid follicles have well-developed germinal centres, and many plasma cells are present around the follicles, particularly in and beneath the overlying crypt epithelium. In trypsinised sections, the PAP method demonstrates a high concentration of $\operatorname{Ig}(\gamma, \alpha$, and $\mu$ heavy chains; $\kappa$ and $\lambda$ light chains) in the cytoplasm of the plasma cells and lower concentrations in many other cells. Not infrequently also a diffuse weak reaction for Ig ( $\mu$ heavy chains; $\kappa$ and $\lambda$ light chains), probably surface $\mathrm{Ig}$, is present over the lymphocyte 'cap' of each lymphoid follicle. Ig-containing cells react more strongly and are better defined and more clearly delineated in the thinner $(2 \mu \mathrm{m}$ and $4 \mu \mathrm{m})$ sections than in the $8 \mu \mathrm{m}$ sections; and detection of individual cells with low concentrations of cytoplasmic Ig is correspondingly easier. Sections thicker than $8 \mu \mathrm{m}$ give unsatisfactory results; the reaction is no stronger than in thinner sections, and the Ig-containing cells frequently over- 
lap. Paraplast sections are slightly less responsive to the PAP method than paraffin wax sections. In contrast to the results with trypsinised sections, very few Ig-containing cells are evident in untrypsinised sections of the same tissues, even when the first (specific antibody) stage of the PAP method is prolonged to 20 hours; and untrypsinised sections left for up to seven days in water or xylol or chloroform remain unresponsive.

Soaking of tissues, during processing, for three days in either alcohol, xylol, chloroform, or hot $\left(56^{\circ} \mathrm{C}\right)$ paraffin wax does not make them reactive, although trypsinised sections of such tissues (except for those treated with xylol) are fully reactive. Tissues left for 24 hours in buffer or buffer-sucrose $(2 \%)$ before fixation are unresponsive, but tissues lightly fixed in formol saline $\left(24\right.$ hours at $\left.4^{\circ} \mathrm{C}\right)$ and then placed in hypotonic $(0.25 \%) \mathrm{NaCl}$ solution for several hours before processing are slightly reactive. If the period in the hypotonic solution exceeds 3 hours, however, deterioration of the histological structure becomes evident. Tissues fixed in buffered formaldehyde or formol saline and then post-fixed in formol sublimate or acetic acid-formol saline remain unreactive.

\section{Solution 3-Aqueous formaldehyde}

In tissues fixed in aqueous (4\%) formaldehyde, small numbers of Ig-containing plasma cells can be detected. The reaction for $\mathrm{Ig}$ is weak, and as $\mathrm{NaCl}$ is added to the fixative in increasing concentrations, the reaction progressively weakens and is practically absent when the concentration reaches $0.8 \%$. As the concentration of $\mathrm{NaCl}$ is increased beyond this level to $2 \%$, the only detectable effect is increasing shrinkage of cells. $2 \%$ formaldehyde-saline gives slightly better results with the PAP procedure than $4 \%$ formaldehyde-saline (formol saline) but it preserves histological structure less well. $1 \%$ (or less) formaldehyde-saline is a poor histological fixative, and the response of the sections to the PAP sequence is equally bad.

\section{Solution 4-Acetic acid-formol saline}

With formol saline containing $5 \%$ or $10 \%$ acetic acid, histological structure is well preserved and nuclear structure is well demonstrated. However, the granules of eosinophil leucocytes are not preserved, and haemoglobin is usually lost from erythrocytes. Collagenous tissue tends to be rendered hyaline in appearance by the $10 \%$ solution. With the PAP method, large numbers of Ig-containing cells are visible, of which only a proportion are mature plasma cells (Figs 1 and 2). The 2\% acetic acid solution gives a less sharply defined localisation of the Ig than the $5 \%$ and $10 \%$ solutions but the number of Ig-containing cells is even greater (Table 2), and Ig is detectable within tingible-body macrophages (Fig. 2). The intensity of reaction is slightly less in tissues fixed for four days than in those fixed for 24-48 hours. The surface Ig, often seen in optimally trypsinised control sections, is only occasionally seen. Background staining, particularly of collagenous tissues, is low, and detection of cells with a small content of cytoplasmic Ig is correspondingly easier. Trypsinisation does not improve the results. As the concentration of acetic acid in the formol saline is reduced below $2 \%$, the number of Ig-containing cells falls progressively, but even when it is only $0.1 \%$ the number of cells is invariably greater than in the negative controls. The results with tissues fixed in $4 \%$ formaldehyde in pH 2 buffer are similar to those obtained with acetic acid (10\%)-formol saline. Tissues prefixed for several hours in formol sublimate before immersion in acetic acid $(10 \%)$-formol saline behave in the same way as tissues fixed only in formol sublimate (see below).

\section{Solution 5-Mercuric chloride}

Tissues fixed in saturated $\mathrm{HgCl}_{2}$ solution often show fairly pronounced shrinkage of cells. The number of Ig-containing cells is comparable to that seen in the positive control sections, and 'surface Ig' is also occasionally seen. $60 \% \mathrm{HgCl}_{2}$ solution gives similar results, sometimes with less marked cell shrinkage. Tissues fixed in saturated aqueous solutions of $\mathrm{HgCl}_{2}$ 'diluted' with $0.85 \%$ saline also respond well immunohistochemically down to about $50 \%$ (ie, equal parts of saturated solution and saline). With lower concentrations of $\mathrm{HgCl}_{2}$, the results are unsatisfactory, both histologically and immunohistochemically.

\section{Solution 6-Formol sublimate}

Localisation of the reaction product is very sharp (Fig. 3), an appearance accentuated by the fixative's tendency to shrink the cells. This tendency appeared to be less when the solution was made up with $60 \%$ aqueous $\mathrm{HgCl}_{2}$ instead of saturated solution. Background staining is not quite as low as with acetic acid-formol saline.

\section{Solution 7-Bouin's fluid}

The number and distribution of Ig-containing cells in tissues fixed in Bouin's fluid (Fig. 4) are similar to those seen in tissues fixed in acetic acid $(5 \%-10 \%)$ formol saline. The reaction product is sharply localised, and background staining is minimal. Trypsin effects no improvement. 48 hours' fixation often gives better results than 24 hours' fixation, but fixation for six days reduces the number of Igcontaining cells. 


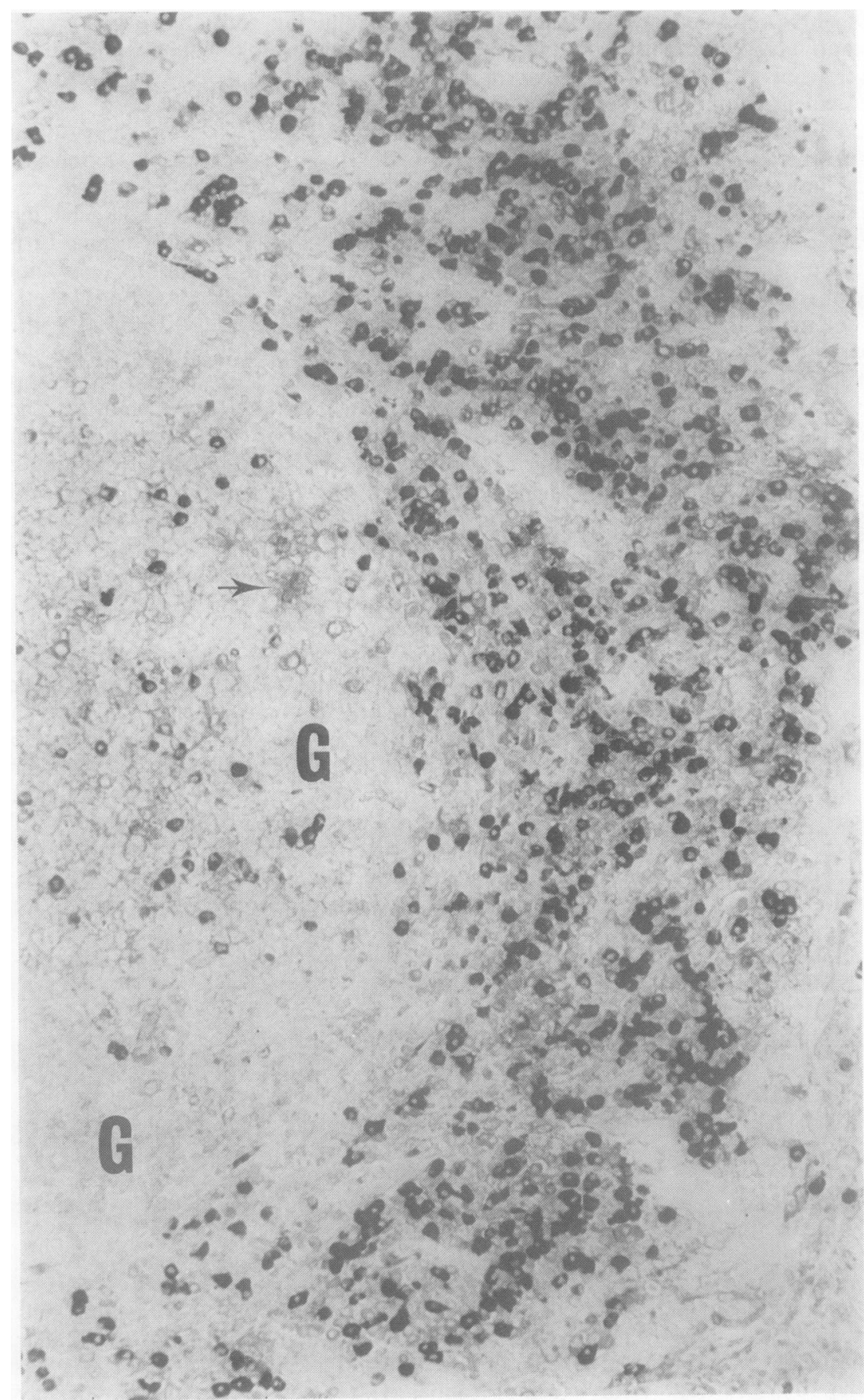

Fig. 1 Tonsil. Half of a germinal centre $(G)$ is covered by a crescent of crypt epithelium (right) in which there are many plasma cells containing $L$ chains (black). Immature plasma cells and 'extracellular' Ig (arrowhead) are present within the germinal centre. Acetic acid (5\%)-formol saline. Paraffin section. $P A P$ method for $L$ chains. $\times 255$.

In the figures, the reaction product for Ig appears black. The nuclei generally appear grey, the nuclear counter-stain having been very largely suppressed by a dense blue filter during photomicrography. 


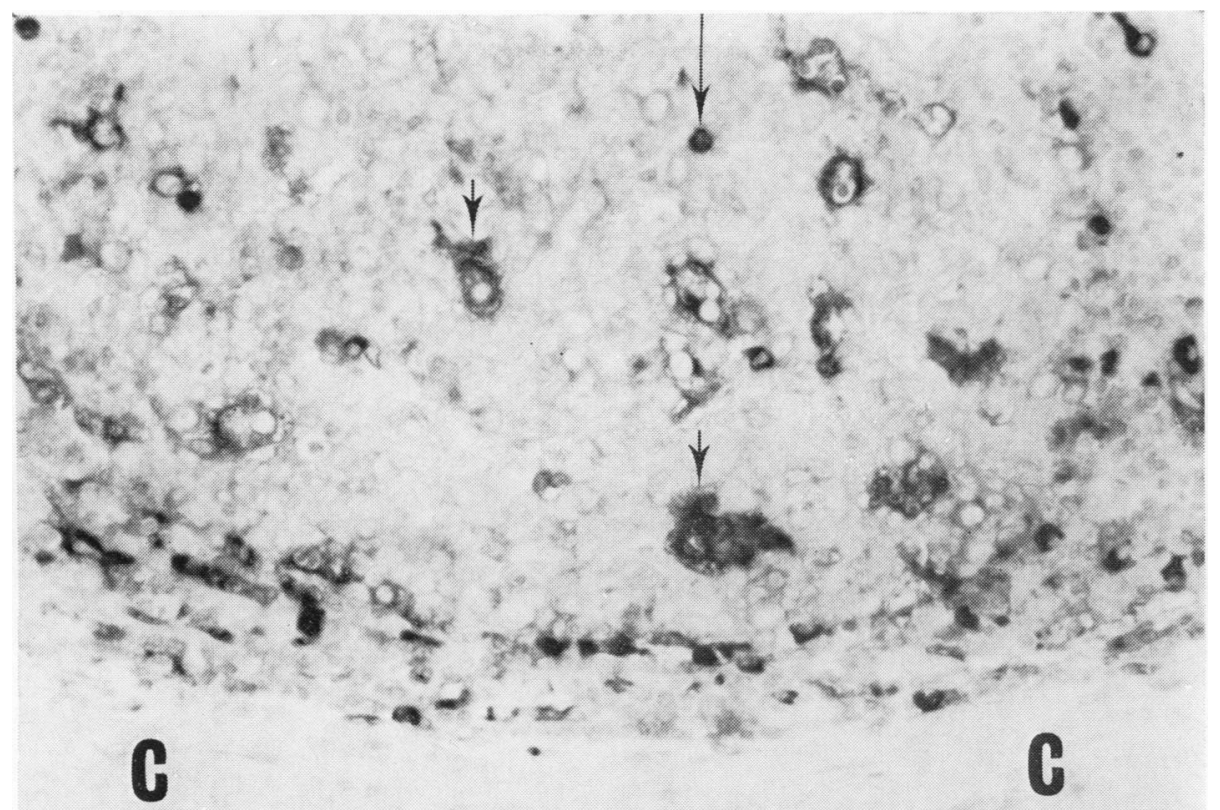

Fig. 2 Tonsil. The base of a germinal centre rests on collagenous fibrous tissue (C). Ig is present in immature plasma cells (arrow) at the periphery of the germinal centre and in tingible-body macrophages (arrowheads). Note the absence of any reaction for Ig in the collagen. Acetic acid (10\%)-formol saline. Paraffin section. PAP method for $\mathrm{K}$ chains. $\times 350$.

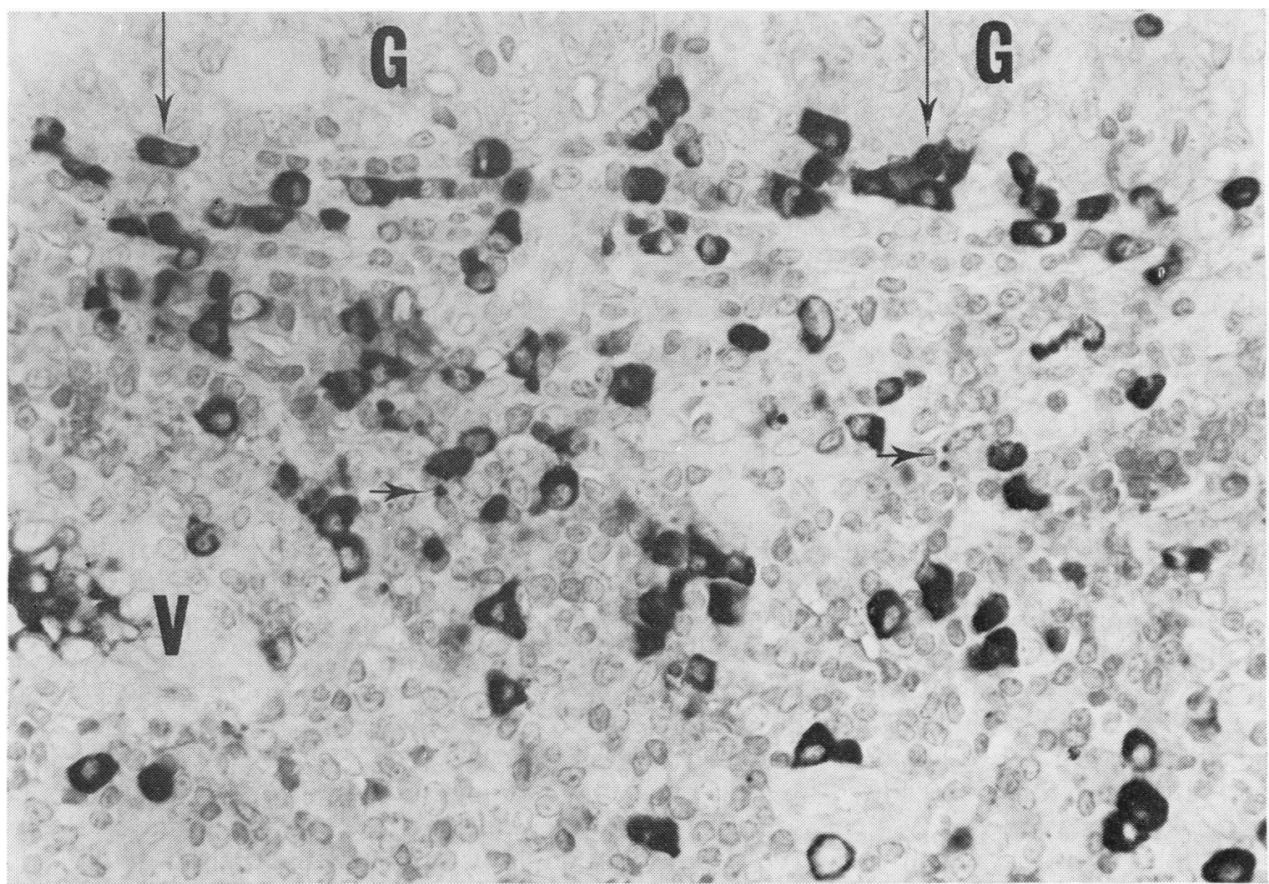

Fig. 3 Tonsil showing part of a germinal centre $(G)$ and lymphocyte-rich tissue beneath the follicle. Plasma cells containing Ig are present around the periphery of the follicle (arrows) and in the adjacent tissue. The reaction product is sharply delineated. In a few cells the amount of Ig is very small (arrowhead). The serum in the lumen of the venule $(V)$ reacts strongly for Ig. Formol sublimate. Paraffin section. PAP method for $K$ chain. $\times 540$. 


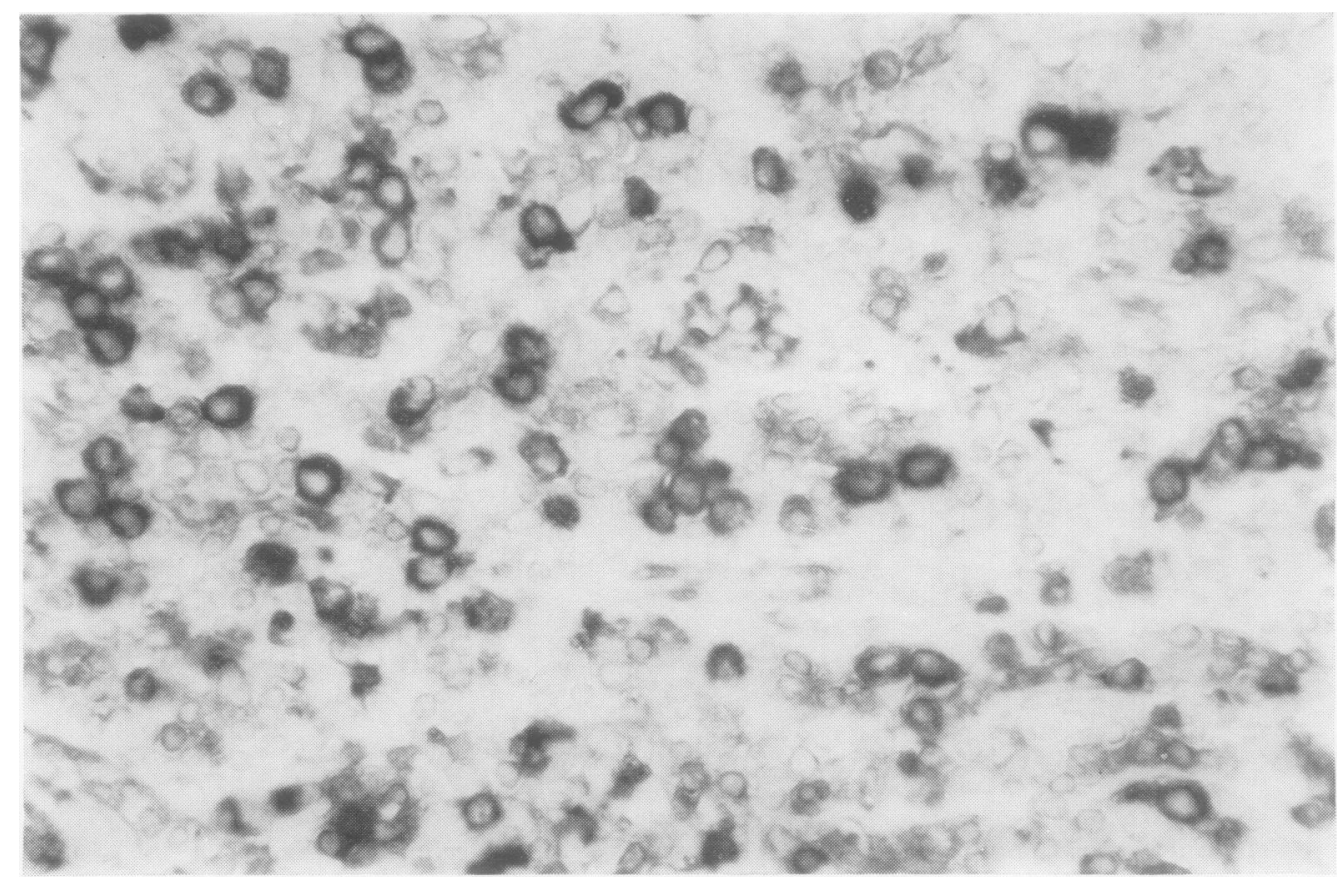

Fig. 4 Tonsil showing tissue adjacent to a lymphoid follicle. Ig is present in low or very low concentration in many cells which tend to form small clusters. These cells looked like lymphocytes in $H$ and $E$ sections. The reaction product is sharply defined in tissues fixed in Bouin's fluid, and the 'soft' appearance here is caused by the very low concentration of Ig in the cells. Bouin's fluid. Paraffin section. $P A P$ method for $K$ chains. $\times 660$.

\section{Solution 8-Carnoy's fluid}

Histological structure is reasonably well preserved with both fixatives, but the sections react unpredictably with the PAP method, Carnoy 1 being slightly better than Carnoy 2. Trypsinisation is without benefit.

\section{BONE MARROW}

Plasma cells with a high concentration of cytoplasmic $\mathrm{Ig}$ are seen in all specimens of normal haemopoietic marrow (Fig. 5). Monoclonality is readily demonstrated in myelomatous infiltrates, cells containing one type of light chain being present in one section (Fig. 6) and no cells containing the other type of light chain being demonstrable in a serial section. Histological structure is reasonably good when acetic acid (10\%)-formol saline is used by itself but the cytological appearances are greatly enhanced when the initial fixation has been in formol sublimate followed by acetic acid (10\%)-formol saline. In sections of tissues fixed initially in acetic acid (2\%)formol saline, Ig is detectable in many megakaryocytes.

\section{Discussion}

The results show that the thickness of the paraffin section has considerable influence on the response to the PAP method and emphasise the need for thin (2-4 $\mu \mathrm{m})$, flat sections free from crushing artefact. In contrast, the various steps in the processing of tissues to paraffin proved to have little influence on the immunohistochemical performance of the sections, as shown by the lack of effect, on fixed tissue, of prolonged soaking in water, alcohol, chloroform, or hot paraffin wax. Processing of tissues intended for use with the PAP method can therefore be unhurried. Ideally, pure paraffin wax should be used rather than wax containing plastic polymers (such as Paraplast), but the increase in sensitivity to the PAP method obtained in this way was moderate and more than offset by the increased difficulty in obtaining sections of the highest quality.

Solutions 1 and 2 (buffered formaldehyde and formol saline, with or without $2 \%$ sucrose) are 'isotonic' solutions which preserve tissue and cellular structure well enough for use in electron 


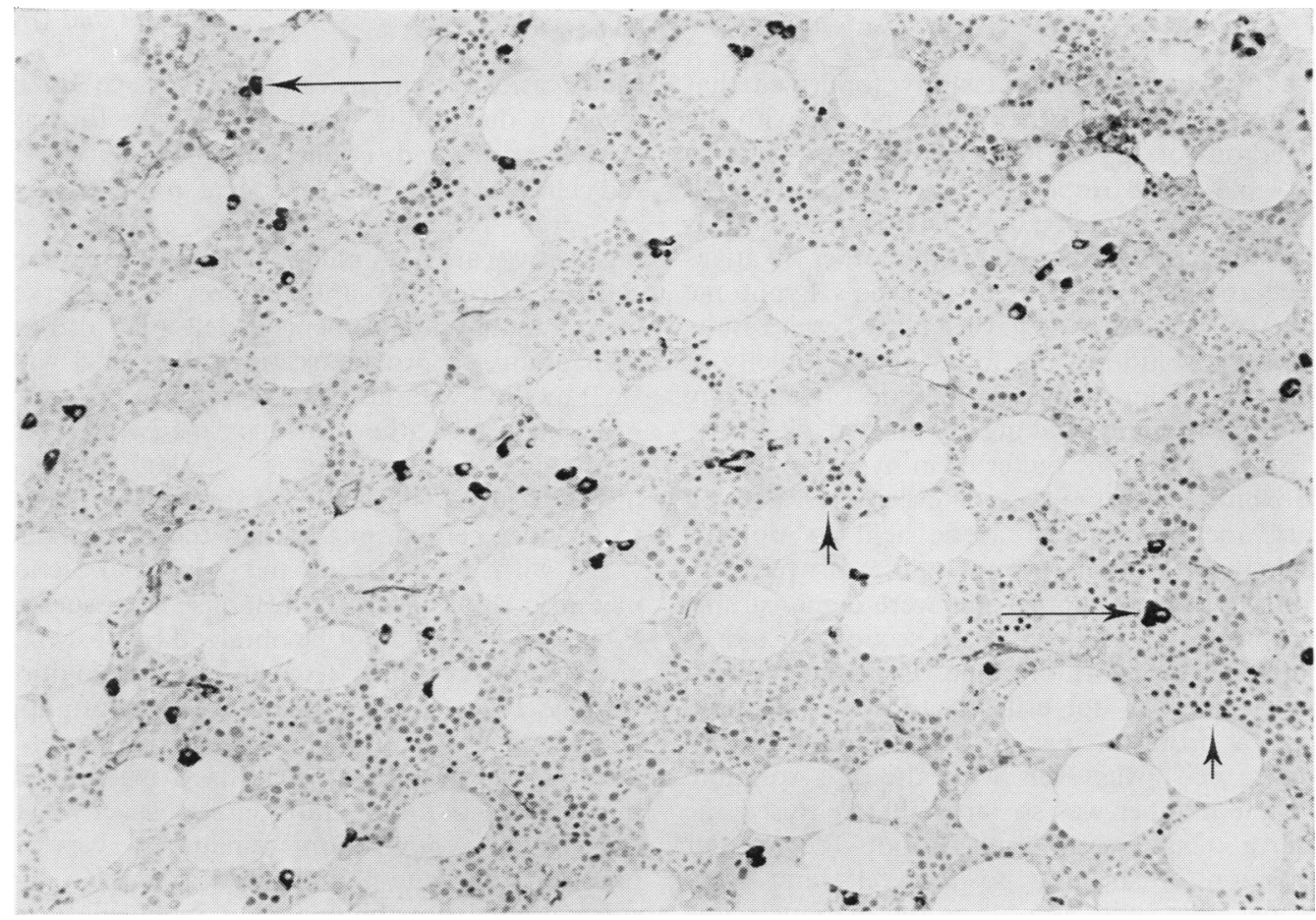

Fig. 5 Normal bone marrow. Mature Ig-containing plasma cells (arrows) are scattered throughout the haemopoietic tissue. The round dark-staining nuclei are cells of the erythropoietic series (arrowheads). Formol sublimate/acetic acid (10\%)-formol saline. Paraffin section. PAP method for K chains. $\times 200$.

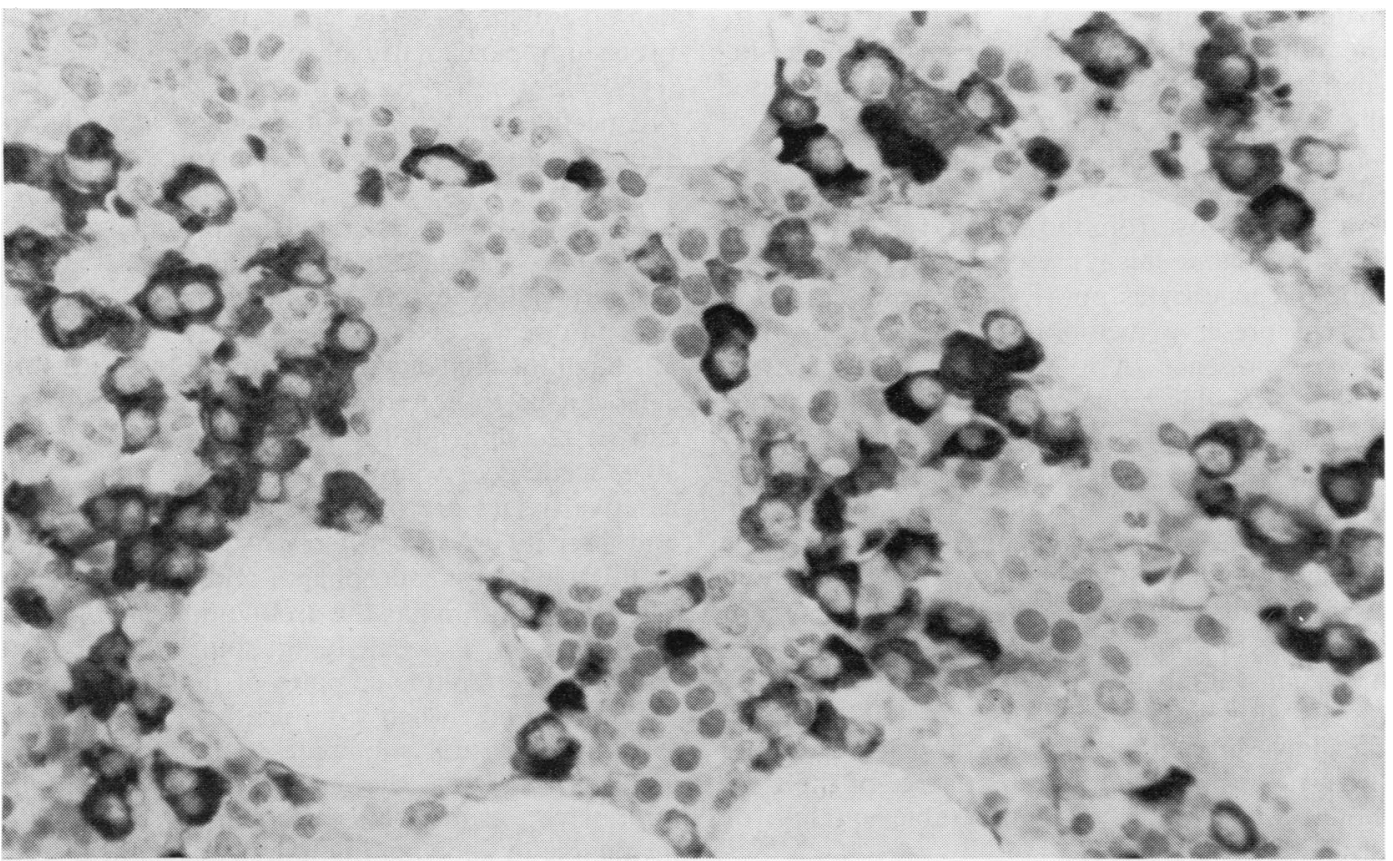

Fig. 6 Bone marrow from a case of multiple myeloma showing many large pleomorphic plasmablasts containing $K$ chains. In a serial section $L$ chains could not be demonstrated in these cells. Formol sublimate/ acetic acid (10\%)-formol saline. Paraffin section. PAP method for $\mathrm{K}$ chains. $\times 660$. 
microscopy, ${ }^{7}$ but the present study confirmed that tissues fixed in either of them react poorly with the PAP method for Ig, ${ }^{14}$ whereas trypsinised sections of the same tissue responded so well to the PAP method that they could be used as 'positive' controls against which performance of the other fixatives could be assessed. Aqueous or markedly hypotonic solutions of formaldehyde gave slightly better results than isotonic solutions, but lowering the tonicity of the fixative was an ineffective method of rendering tissues reactive; and soaking of unfixed or lightly fixed tissues in isotonic buffer or in hypotonic saline before isotonic fixation was of even less value. In contrast, the addition of acetic acid to isotonic formaldehyde solution (formol saline) proved very effective, and Ig-containing cells were demonstrable in large numbers in untrypsinised sections of tissues fixed in acetic acid-formol saline. The concentration of acetic acid was not critical, and 'over-fixation' was not a problem. The greatest number of $\mathrm{Ig}$ containing cells was seen with the $2 \%$ solution. Indeed, the number was so large that it raised the possibility of diffusion artefact, but the regular juxtaposition of strongly positive cells and completely negative cells, as well as the extremely low background staining, made this very unlikely. Unfortunately, the beneficial effect of acetic acid was not obtained by post-fixing tissues previously fixed in isotonic formaldehyde in acetic-acidformaldehyde solution.

The mode of action of the acetic acid in increasing the permeability of cells to the large molecules used in the PAP method is unknown, but the failure of the acetic acid-formol saline to preserve the cytoplasmic membrane of erythrocytes (the haemoglobin generally being lost from the cells) is relevant. Acetic acid-formol saline also preserves the granules of eosinophilic leucocytes poorly, suggesting a general failure to preserve membranous structures within cells. The presence of a high degree of cell permeability after this mode of fixation was confirmed by the inability of trypsin to improve the response of sections to the PAP method. Failure to preserve the cytoplasmic membrane of cells would also explain the difficulty encountered in demonstrating Ig on the surface of the small B lymphocytes of the lymphoid follicles. Presumably acetic acid exerts a similar action in Bouin's fluid and Carnoy's fluid, the results with Bouin's fluid being comparable with those obtained with acetic acid (5\% or $10 \%)$-formol saline. However, neither of the Carnoy fluids, despite the h!gh titres possible in the first stage of the PAP method, gave results of comparable quality or consistency.

Solutions containing mercuric chloride also gave worthwhile results with the PAP method, including the occasional demonstration of surface Ig. Histologically the results, particularly with formol sublimate, were good, confirming previous work, and red cells and eosinophil leucocyte granules were well preserved. Nevertheless mercuric chloride-containing fixatives are not noted for their ability to preserve cell ultrastructure; and failure to preserve the membranous compartments of cells may also explain their ability to provide sections that react with the PAP method without prior trypsinisation. Immunohistochemically the various mercuric chloridecontaining solutions gave similar results, but histologically a $60 \%$ aqueous solution was less likely to produce cell shrinkage than the other solutions.

As with acetic acid, the beneficial action of mercuric chloride on the response of tissues to the PAP method could not be obtained by post-fixation, and tissues previously fixed in isotonic solutions of formaldehyde (solutions 1 and 2) were not improved by subsequent fixation in formol sublimate. Most 'routine' surgical tissues are fixed in isotonic formaldehyde solution, and for retrospective studies on these, trypsinisation remains a very useful procedure, despite the theoretical but so far unsubstantiated possibility that it might cleave tissue antigens to yield fragments common to many determinants. ${ }^{8}$ Indeed, in the present study it was only in trypsinised sections of tissue fixed in isotonic formaldehyde that surface Ig could be regularly demonstrated. Nevertheless it is a time-consuming procedure, particularly since the optimum degree of trypsinisation has to be determined; and when a prospective study is contemplated, consideration should be given to using a fixative that works without trypsinisation.

Bouin's solution is a reasonable alternative, as others have shown. ${ }^{9}$ So, too, are solutions containing mercuric chloride, and especially formol sublimate, which preserves cytological structure very efficiently, although the tendency of mercuric chloride to shrink cells can be troublesome. Acetic acid-formol saline can be recommended as very effective. The $5 \%$ or $10 \%$ acetic acid solutions work well, but the most reactive tissues are obtained with the $2 \%$ solution. and after its use Ig is often detectable, for example, in tingible-body macrophages and megakaryocytes. The $10 \%$ solution has the useful additional property of acting as a decalcifying solution, completely decalcifying trephine samples of iliac crest bone in 48 hours and, when combined with preliminary fixation in formol sublimate to improve the cytological detail of the haemopoietic cells, gives impressive results. This technique should prove invaluable in allowing immunohistochemical studies to be made on a tissue which in the past has proved difficult to use for this purpose, particularly since 
unpublished results show that other antigens can be demonstrated readily.

We thank Miss Valerie Esland for typing the manuscript and Miss Philomena Byrne for assistance with the photography. Generous financial support was provided by the Endowment Fund Medical Research Committee of the Central Birmingham Health District.

\section{References}

1 Taylor CR, Burns J. The demonstration of plasma cells and other immunoglobulin-containing cells in formalin-fixed paraffin-embedded tissues using peroxidase-labelled antibody. J Clin Pathol 1974;27:14-20.

2 Curran RC, Jones EL. Immunoglobulin-containing cells in human tonsils as demonstrated by immunohistochemistry. Clin Exp Immunol 1977;28:103-15.

${ }^{3}$ Curran RC, Gregory J. The unmasking of antigens in paraffin sections of tissue by trypsin. Experientia 1977; 33:1400-1.

${ }^{4}$ Curran RC, Gregory J. Demonstration of immunoglobulin in cryostat and paraffin sections of human tonsil by immunofluorescence and immunoperoxidase techniques. J Clin Pathol 1978;31:974-83.

${ }^{5}$ Carson FL, Martin JH, Lynn JA. Formalin fixation for electron microscopy: a re-evaluation. Am J Clin Pathol 1973;59:365-73.

- Sternberger LA, Hardy PH Jr, Cuculis JJ, Meyer HG. The unlabeled antibody enzyme method of immunohistochemistry. Preparation and properties of soluble antigenantibody complex (horseradish peroxidase-antihorseradish peroxidase) and its use in identification of spirochetes. J Histochem Cytochem 1970;18:315-33.

${ }^{7}$ Robinson G, Dawson I. A formalin fixative for immunochemical and ultrastructural studies on gastrointestinal endocrine cells. J Clin Pathol 1979;32:40-5.

${ }^{8}$ Heyderman E. Immunoperoxidase technique in histopathology: applications, methods and controls. J Clin Pathol 1979;32:971-8.

- Bosman FT, Lindeman J, Kuiper G, Van der Wal A, Kreunig J. The influence of fixation on immunoperoxidase staining of plasma cells in paraffin sections of intestinal biopsy specimens. Histochemistry 1977;53:57-62.

Requests for reprints to: Professor RC Curran, Department of Pathology, The Medical School, Birmingham B15 2TJ, UK. 